\title{
Poles in the Dutch Cape Colony 1652-1814
}

\author{
MARIUSZ KOWALSKI \\ Institute of Geography and Spatial Organization \\ Polish Academy of Science \\ Instytut Geografii i PZ PAN \\ ul. Twarda $51 / 55$ \\ 00-818 Warszawa, Poland \\ mar.kow@twarda.pan.pl
}

\begin{abstract}
The contribution of Poles to the colonisation and development of the Dutch Cape Colony is not commonly known. Yet, Poles have been appearing in this colony since its very inception (1652). During the entire period considered here the presence of Poles was the result of the strong economic ties between Poland and the Netherlands. At the end of this period there was an increase in their share, in connection with the presence of numerous alien military units on the territory of the Colony, because of Poles having served in these units. Numerous newcomers from Poland settled in South Africa for good, established families, and their progeny made up part of the local society. The evidence of this phenomenon is provided by the present-day Afrikaner families of, for instance, Drotsky, Kitshoff, Kolesky, Latsky, Masuriek, Troskie, Zowitsky, and others. A quite superficial estimation implies that the settlers coming from Poland could make up a bit over $1 \%$ of the ancestors of the present-day Afrikaners. Poles would also participate in the pioneering undertakings within the far-off fringes of the Colony, including the robbery-and-trade expedition of 1702 .
\end{abstract}

Keywords: Poles; South Africa; Dutch colonisation; British occupation 


\section{Introduction}

The participation of Poles in the Dutch colonisation of South Africa is not commonly known. Among the few pioneers of investigations, concerning this subject, one should mention Arkadiusz Żukowski. He refers to the contemporary Polish community in South Africa as well as earlier cases of Polish presence in the Dutch Cape Colony (Źukowski 1994, 2001, 2005). Among the persons described there are, first of all, the founders of several of the Afrikaner families (for example Kitshoff, Latsky, Sowietsky, Troskie). I was inspired by the work of A. Żukowski. Following his footsteps I tried to broaden the existing knowledge concerning the Poles mentioned, and to get acquainted with the unknown episodes from their lives, as well as the stories of other Poles, who appeared in the same period in the southern part of Africa.

This article is an attempt to investigate the issues, related to the presence of Poles in the Cape Colony for its entire Dutch period. It is an effort to put the questions I have been asking in my studies to date into a coherent whole (Kowalski 2006, 2009, 2012), these previous studies concerned only selected fragments of the period, or only selected problems. Thereby, an opportunity also arose of considering some new themes and thoughts. The temporal frame of the report is determined by the date of the establishment of the colony by Jan van Reebeck and the date of the formal handing over of the authority over the land to the British. The years 1795-1814 constituted a transitory period, during which the Colony was under the British occupation. Yet, during this entire time interval the Dutch institutions and the legal system were preserved and there was, neither, a mass British immigration to the Colony. Just like it has been during the last decades of the Dutch rule, the majority of settlers were the soldiers, who terminated their military service in the Colony. Similarly as in the past, even though being frequently of British extraction, they would marry Boer women, and their progeny would enter and magnify the Boer society. The first British proper colonisation action, aimed at the strengthening of the British element in the Colony that occurred in 1820 .

The inhabitants of the Polish-Lithuanian Commonwealth were strongly differentiated in ethnic, language, and religious terms. In this context, a particular place among the regions of the Commonwealth was occupied by Prussia, divided into the Ducal (with Königsberg) and Royal (with Gdańsk) parts. Side by side with the dominating Polish-speaking population, this area was inhabited by the communities speaking the dialects of the Cassubian, German and Lithuanian languages.

Yet, one can hardly speak of the ethnic divisions in their contemporary form, regarding the times considered here. There was the political Polish nation, whose 
essential and most privileged portion was constituted by - irrespective of their ethnic origins - the representatives of the nobility. The richest of the Prussian townsfolk (including Gdańsk) made up a part of this privileged class. Furthermore, the totality of the bourgeois (who, in Prussia, were German speaking in their majority) enjoyed broad citizenship privileges in the framework of the Polish political community. All the inhabitants of the country were also the subjects of the Polish king. Thus, irrespective of their ethnic origins, language spoken, the sound of the names, and religious denomination, all were Poles in the political sense of the word.

Given these circumstances, the present elaboration treats Poles as all of the subjects of the Polish kings, irrespective of their ethnic classification, which is, anyway, in frequent cases hard to establish. This population includes here also the inhabitants of Ducal Prussia, since this region - despite the formal severing of the political links with the Polish-Lithuanian Commonwealth (mostly in 1657, finally in 1701 - the last adjustment recognised by Poland in 1764) - was still maintaining strong cultural, economical and political relations with the Commonwealth ${ }^{1}$ and, in addition, formed geographically an enclave, surrounded by the territories of the Commonwealth.

The presence of the emigrants from Poland in the first decades of the Colony was the outcome from the Polish-Dutch economic and cultural ties. The main purchaser of Polish products (mainly from agriculture and forestry) were the Netherlands, while Poland was an important purchaser of luxury goods of Dutch production or of the ones imported by the Dutch from overseas. The majority of vessels coming to the Polish ports came from the Netherlands. There was an important mutual migration movement between the two countries. One might speak of an informal Dutch-Polish economic union, in which the Netherlands were definitely the dominating partner. Poland did not have an extensive fleet, nor owned colonies, and instead concentrated on the development of the settlement system and economy on its own territory. For these reasons, numerous inhabitants of Poland, especially of the coastal regions, in view of the close Polish-Dutch ties, would enrol in the Dutch fleet and in the Dutch colonial armed forces. The Germanic dialects, which were quite common in many places in Poland (like, e.g., the Lower-Prussian dialect), facilitated contact, due to their similarity to the Dutch language (Kowalski 2012: 57).

The database of the payroll of the Dutch East India Company demonstrates that several thousand Poles enroled in the $17^{\text {th }}$ and $18^{\text {th }}$ centuries in this

\footnotetext{
${ }^{1}$ Till 1657 the ruler of East Prussia was a vassal of the Polish king due to wield other territories. But even later there was a great deal of Polish influence there. There was still numerous Polish speaking communities in the region. Its inhabitants still maintained strong relations with Poland and Lithuania, especially with Royal Prussia.
} 
organisation. Their presence in the colonial forces of the Dutch East India Company in the $17^{\text {th }}$ century is confirmed by the report from the surgeon Nicolas de Graaff, who was five times on service in the East Indies in the years 1639-1683. In his memoirs, published after his death (in 1701) he recalls that the service in the Company was refuge for the representatives of such nationalities as "Polakke, Sweeden, Deenen, Noor-luyde, Jutte, Hamborgers, Bremers, Lubekkers, Dantsikers, Koninxbergers, Hoogduytse, Oosterlingers, Westfaalders, Bergse, Gulikse, Kleefse en voorts alderhande Moffen, Poepe, Knoete en Hannekemaijers en andere groene kassoepers." This list not only puts Poles (Polakke) in the first place, but also mentions the representatives of the Polish coastal cities (Dantsikers inhabitants of Gdańsk, Koninxbergers - of Königsberg). At the end the term kassoepers appears, most probably originating from the name of Kaszubi - Polish inhabitants of the southern coast of the Baltic Sea (Van Gelder 1997: 54-55). Several decades later, two Poles, Georg Nappora (1731-1792) and Anzelm Teodor Dzwonkowski (1764-1850) also wrote down their memories from the time of their service in the Company. Their notes persisted through the turbulent times and were published in the second half of the $20^{\text {th }}$ century (see Dzwonkowski 1985; Van Gelder 2003), providing evidence for the contribution of Poles to the Dutch colonial undertakings in the Eastern hemisphere.

\section{The first decades of the Dutch South Africa}

\subsection{The beginnings of colonisation}

The Cape Colony was property managed by the East India Company, and so the presence of emigrants from Poland - given the circumstances mentioned before - was a regular situation. At least one Pole, Paulus Petkow (Petkouw), born in Gdańsk, was a member of the van Riebeeck's crew, establishing the Cape Colony in 1652. At the time the Dutch expedition reached the Cape, Petkow was only a cadet, but he quickly gained the trust of van Riebeeck and when one of the junior officers got degraded, he was appointed to the vacant post. Owing to this promotion the emigrant from Poland took part in the first war council, convened by the Dutchmen in South Africa, which occurred on October $10^{\text {th }}, 1652$. His signature can also be found under the protocols from the three subsequent war councils. The commander was apparently satisfied with the service of the man from Gdańsk, for on December $6^{\text {th }}, 1652$, advanced him to sergeant (Leibbrandt 1897a: 9-17; Höge 1946: 311; Kowalski 2012: 60).

Another emigrant from Poland, who also distinguished himself in the service, was also a man from Gdańsk, Jan Liske (Liskij), who came to the Colony four years after its establishment (1656). He was initially an assistant to a cadet, and 
then to a sergeant, in the service of the Company, but already in 1657 gained the status of a free settler (citizen of the Colony). In 1659 he participated in the sevenperson expedition to the Namaqua tribe, living 20-30 days of travel North of the Cape of Good Hope. This was, most probably, the very first significant exploratory expedition into the African interior (Fig. 1). In 1660 Liske worked as a hand on a farm owned by a widow of one of the Dutch settlers. Life in the Colony did possibly not meet his expectations, for in the same year he returned (illegally) to Europe (Leibbrandt 1897b: 4; Höge 1946: 244; Kowalski 2012: 60).

During the first decades of the Cape Colony, the presence of soldiers and settlers from the Polish-Lithuanian Commonwealth became a kind of norm. Best known are the fates of Peter Mow, Claes Barenski, and Jan Demant. All three originated from Gdańsk, and all of them had problems associated with their service in South Africa. For some of them this ended tragically. Side by side with the inhabitants of the coastal regions of Poland, emigrants from the areas farther inland started to appear. One of them was Jerzy Botkiewicz (Jurgen Botkewitz or Potkiviet in documents) from Warsaw. He came to the Colony as a soldier in 1674, and after having terminated his service, stayed as a free citizen. He was, most probably, the first Pole, who settled in South Africa for good (Kowalski 2012: 62-63).

\subsection{The rule of the governors from the Van der Stel family}

Intensification of the colonisation action coincided with the rule of the governors from the Van der Stel family (1679-1707). In 1688 a large group of settlers was brought in (some 80 families), composed of the French Protestants (see Mentzel 1921: 66). In this period both soldiers and settlers from the Polish-Lithuanian Commonwealth came as well. This fact could be associated with the personal connections of the involved governors. One of the sons of Simon van der Stel, Henrik (1670-1722), who spent a long time (1679-1686) in the Cape Colony, married Constantia Abrahamsz, a Polish woman originating from Gdańsk. The couple spent a year in the Cape (1703-1704) on their way to the Dutch Indies, where Henrik was to take over the management of the Company office in Makassar. The increase in the number of Poles, who came to the Cape Colony, could also have roots in the stimulus to the maritime policy of the Polish-Lithuanian Commonwealth given under the reign of Jan III Sobieski (Kowalski 2012: 56, 63, 70).

Among the settlers from Poland persons coming from Prussia dominated, either from Royal or from Ducal Prussia. ${ }^{2}$ The latter became independent

\footnotetext{
${ }^{2}$ Royal Prussia belonged to the Kingdom of Poland directly, while Ducal Prussia (later: Duchy of Prussia or East Prussia) up to 1657 was separate part of the monarchy put in a fief for the Hohenzollern dynasty. Full sovereignty of that country, as a Kingdom of Prussia, was established in 1701. Polish-Lithuanian Commonwealth recognized it only in $1764 \mathrm{r}$.
} 
politically from Poland in 1701, but strong political, economic and cultural ties persisted. The settlers from these regions were dominated by the persons from Gdańsk and Königsberg. The Slavonic-Germanic character of the region caused that the names of these persons had Germanic or Slavonic origins. Among the latter one can mention Michiel Kowalski from Königsberg and Ludwig Romejk from Żądzbork. Yet, persons with Germanic sounding names were most common. Those coming from Gdańsk included (dates of appearance in the Colony are given in brackets): Michiel Mester (1680), Laurens Campher (1686), Bartholomeus Nachtigal (1687), Peter Henderikse (1687), Martin Mecklemburg (1688), Paul Maron (1691), Jan Knuppel (1692), Godfried Rode (1693), Jan Maron (1694), Jan Brouwer (1695), Peter Malmer (1700). Then, from Königsberg came: Andreas Quertvoet (1680), Jan Andresen de Jonker (1684), Christoffel Weert (1686), Christoffel Grunwald (1688), Peter Becker (1695), August Bitzier (1695), Andreas Verreyn (1696), Michiel Klein (1696), Jakob Hofland (1697), Valentin Kleinveld (1701), Tomas Eysman (1704). Some of them established the Afrikaner families that exist until today: Bekker, Campher, Eyman, Groenevald. The lineage of other settlers died off sooner or later (e.g. Malmer), or found continuation through the female descendants (Knuppel, Mecklenburg) (Höge 1946: 21, 57, 93, 122, 256; Kowalski 2012: 63-66; Robertson 2014).

Nowadays, the family of Groeneveld is particularly numerous. The founder of this family had a Germanic family name and came from (or at least so declared) Königsberg, dominated by the German-speaking population (the Polish population accounted for only $1 / 4$ of the people in the city). Yet, this is not enough to say that he was a German, insofar as on the ethnically mixed area the name was not unambiguous evidence of ethnicity. Both now and in the past numerous Poles bear German-sounding names (including the name Grunwald). Mixed origins of the population of the Duchy of Prussia, as well as a long-lasting political connection with the Kingdom of Poland, do not allow for the unique ethnic-cultural classification of its inhabitants. One could speak of the population of the PolishGerman cultural borderland, where Polish and German influences got mixed. Some speak of a separate, specific Prussian historic nation, having developed under the influence of German, Polish, Pomeranian (Cassubian), Old Prussian and Lithuanian cultures. These circumstances are indicated, in particular, by Roelof van Gelder (2003) in his study of Georg Nappora, another inhabitant of Ducal Prussia (who settled later in Gdańsk), having served for five years (17521757) on a vessel of the East India Company.

The number of soldiers from Poland was several times bigger than the number of settlers. Many soldiers would spend more than ten years in the service (Kowalski 2012). This group included the former inhabitants of Gdańsk (dates of arrival in brackets): Albert Bolenski (1695), Martin Streik (1695), Martin Beenen (1695), 
Peter Wagner (1695), Henrik Tessner (1696), Christian Didelof (1697); as well as those coming from Königsberg: Jurgen Smacke (1695), Jurgen Altrok (1695), Jan Beernik (1699), Paul Bokanowski (1705); from other parts of Polish Prussia: Martin Zabrewski (1697), Christoffel Tym (1699), Simon Zaborowski (1704), Antony Siglenski (1703), Jan Ertel (1705), and from the remaining parts of Poland and of the Commonwealth as a whole: Albert Bernewitz (1673), Martin Hamerling (1685), Jan Bolonie (1699), Tomas Tyl (1699), Jan Monsewicz (1701), Konstantin Kompenski (1701) (Nationaal Archief 2012; Kowalski 2012: 71-73). Numerous soldiers were rented out to work on the farms, this being an opportunity for them to integrate with the local community. Sometimes (perhaps not quite by chance) they would work on a farm owned by a settler from the Polish-Lithuanian Commonwealth. Jan Tollenar was hired out to Martin Meklenburg, while Michiel Kowalski was employed by Jan Knuppel. After a period of time some of them (like Kowalski, Romejk, Kleiveld, Eysman) would also acquire the status of settlers (Kowalski 2012: 63-68).

One of the hypotheses is that South Africa was also a refuge for a group of the Polish Brothers, an Arian denomination (Źukowski 1994: 69). They were banished from Poland for having taken the side of the Swedish aggressors during the war in the middle of the $17^{\text {th }}$ century, that is - just after the beginning of the Dutch colonisation of South Africa. Having left the Polish-Lithuanian Commonwealth, they settled in the Duchy of Prussia, in the Netherlands, in Silesia, in Transylvania, and in the German countries. Zbigniew Morsztyn, leader of the Polish Brothers in Ducal Prussia, considered (at around 1671) the possibility of moving together with the persecuted faithful, to one of the Dutch properties within the Eastern hemisphere. This idea, however, was not realised. Yet, it cannot be excluded that some of the settlers in South Africa, originating from the Netherlands, Germany, Silesia, Ducal Prussia, or even from the territories of the Commonwealth, had belonged to this religious group, or originated from it. There are some premises for suspecting that this could be the case of Joost Stredon and Henry Fenter, who came from the Netherlands, and who founded two Afrikaner families that are very large today: Strydom and Venter (Kowalski 2012: 63).

Some settlers and soldiers from the Polish-Lithuanian Commonwealth left their imprint on the history of the first decades of the Colony. Martin Hamerling from Poznan came to the Colony in 1685 as a cadet. In 1695, already a corporal, he became, similarly as did Albert Bernevitz from Courland earlier on, the commander of a strategic post on Robbeneiland. In 1701 Hamerling advanced to sergeant and commanded ten soldiers (at the end of his service this number increased to 16). At the beginning of 1707 he welcomed the new governor of the Cape Colony, Luis van Assenburg, with a kind letter. He was the commander of 
the post on Robbeneiland until 1721, having thus served there the longest, and having proved during his term many times his engagement and devotion to the service (Kowalski 2012: 65).

\subsection{Expedition to the Cabuquas people of $\mathbf{1 7 0 2}$}

One should mention also a group of Poles, who made history by participating in 1702 in the expedition to the Cabuquas people. Owing to this expedition the European settlers encountered for the first time the representatives of Bantu tribes (most probably the Xhosa people). This encounter ended with the very first armed clash between the two communities. The seven-person group of organisers and leaders of the expedition included Michiel Kowalski and Jakob Hofland from Königsberg, and Tomas Tyl from Warsaw. The official purpose of the undertaking was to be the barter trade with the Hottentot tribes. In reality, trade relations with the Bantu tribes were the true purpose, along with the appropriation of their cattle herds. There were at least two other participants in the expedition, coming from Poland: Henrik Tessner and Bartholomeus Nachtigal (both from Gdańsk). The settler Jan Knuppel, who provided the expedition with a cart, also came from Gdańsk. The undertaking was sponsored by many other settlers of the Cape Colony. The whole expedition included 90 men, 45 Europeans and 45 servant Hottentots (Khoi-Khoi). They were equipped with four carts and 32 pulling oxen, as well as 14 horses for riding (Kowalski 2012: 66-68).

They took off on March 23 $3^{\text {rd }}, 1702$, and returned after two months. The expedition went in the eastern direction from the then Cape Colony. After having passed the mountains Hottentots Hollands Kloof, the expedition crossed the territories inhabited by the tribes of Khoi Khoi: Sousequas, Hessequas, Gmiris, Attaquas, Gamptouwers, Dammaquas and Moetjensans (Cochesous) (Fig. 1). From the latter tribe several guides and translators were hired. Trade with the Bantus did not work out. In the vicinity of the Groot-Vis river (nowadays in the Eastern Cape Province) the colonists were attacked by a group of 500-600 Xhosa warriors (Cabuquas tribe). The attack was repelled. In the fighting more than 20 African warriors were killed and one of the colonists. Despite this success, in the view of the lack of gunpowder, the colonists gave up and returned. On their way back they attacked the Hottentot tribe Inqua and took away from them a large herd of cattle (two thousand animals) and of sheep (also two thousand). This booty was split up among the participants of the expedition (Kowalski 2012: 66-68).

This expedition had a truly pioneering character, reaching as far as $700 \mathrm{~km}$ to the East of Kaapstad (Cape Town), up to the area of Groot-Vis river and Bruintjes Hoogte hills. On the way, the colonists crossed several ranges of the Western Cape Mountains (Hottentot Holland, Langeberge, Kammanassie, Kouga, 


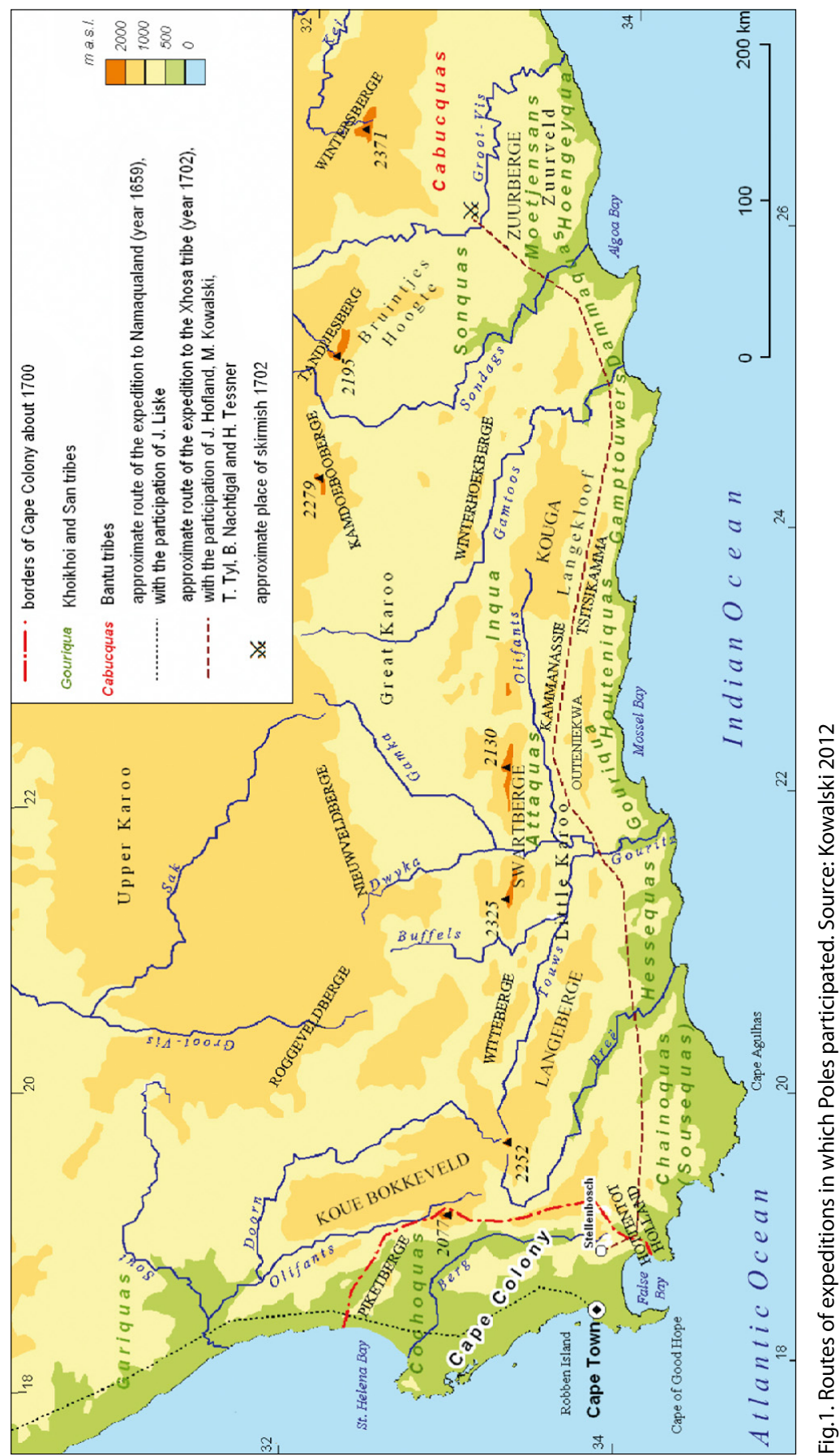


Tsitsikamma, Zuurberge, Winterhoekberge, Swartberge), the Little Karoo dale, the vast Langkloof valley, as well as several rivers, flowing to the Indian Ocean (Bree, Gouritz, Groot-Gamtoos, Sondags, Groot-Vis) (Fig. 1). The official expedition, which preceded the one here described, and had taken place in 1689, which was headed by Isaq Schrijver, went $100 \mathrm{~km}$ closer, reaching merely the upper course of Sondags river. It was only the expedition of hunters, led by Hermanus Hubner in 1736, that reached the territory of Pondoland, situated farther East. The route of Hubner was also repeated in 1752 by the official colonial expedition, whose commander was cornet August Frederik Beutler (Kowalski 2012: 66-68).

The undertaking here described brought about a discontent of the authorities of the Colony, who ordered a detailed investigation into the matter. Despite the negative evaluation of the undertaking, it was decided not to punish the participants nor the sponsors. Yet, trade with African tribes got formally forbidden. New regulations worsened the relations between the authorities of the Colony and the settlers, and brought about an open protest in 1706 . This resulted, on the one hand, in the recalling of the governor, but, on the other hand - motivated the authorities to limit the inflow of new colonists. This date is considered to mark the end of the initial phase of the history of the Cape Colony. Thus, the several hundred settlers, having come before that date, including a handful of emigrants coming from Polish territories (like Campher, Grunwald, Knuppel, or Meckelenburg), became the founding fathers of the Afrikaner community (Kowalski 2012: 66-68).

Nothing is known of the further fates of the Polish organisers of the expedition. The sole information is that Hofland and Kowalski gained the status of citizens of the Colony. The first of them in 1702, the second - in 1706. We know, on the other hand, much more of the rank-and-file member of the expedition, Bartholomeus Nachtigal from Gdańsk. He came to the Colony in August 1687 on board of Oostsouburg ship. In 1690 he gained the status of citizen, but in 1696, after having attacked the Company guards, he was sentenced to two years of hard labour, flogging and branding. The sentence of the jury says that the 40 year old Nachtigal was at that time a wanderer without a permanent address, moving around the country with his blunderbuss, gunpowder and plumb. Only in 1702 he settled in a far-off corner of the Drakenstein district. This might have become possible owing to the participation in the expedition here described, as he obtained a cattle and sheep herd in the outcome of the undertaking. In 1710 he got employed as a shepherd by a farmer. In 1714, just before his death, he signed a contract with another farmer, who, in exchange for the legacy of the herd of 300 sheep, took obligation of feeding, accommodating, and - after the death of Nachtigal - of burying him (see Höge 1946: 290; Shell 2005: 23; Nationaal Archief 2012; Kowalski 2012: 66). 


\section{The golden age of the Dutch South Africa (1707-1778)}

The revolt of the inhabitants of the Cape Colony in 1706 was decisive for slowing down the mass settling of the Europeans. This was, therefore, the end to the initial period of the European colonisation. Yet, it was not the end to the inflow of emigrants. The freewill newcomers, taking up service or work in the East India Company were still arriving at the Colony. Most of them were soldiers and mariners. Again, there were also Poles among them. A part of these newcomers would settle after having terminated their service and establish families.

The Poles, who served at the Cape, similarly as during the first decades of colonisation, originated primarily from Polish Prussia. Sometimes, though, emigrants from other regions of the Polish-Lithuanian Commonwealth arrived as well. The following persons served at least a couple of years at the Colony (year of arrival is given in brackets): Antony Zawołocki (1760) and Barent Jakobs (1731) from Kraków, Józef Gocki (1745) from the region of Małopolska, Jan Baruski (1744) from Warsaw, Jan Borski (1758) from Poznań, Jan Salus Miller (1770) from Rawicz. Then, Ferdinand Bartoszewski (1746), Jan Christoffel Sikora (1756), Jan Wotski (1767) and Wilhelm Hooyer (1744) came from Courland, while Franciszek Sawicki (1746-1750) and Dawid Mucki (1717-1729) came from undefined places in Poland (Höge 1946: 173, 285, 359, 472; Nationaal Archief 2012).

The list above mentions, in particular, Dawid Mucki. He started his service for the East India Company in 1717. It is known that in 1727 he was in Cape Town, from where he was sent by his superiors to Rio de la Goa (nowadays Maputo in Mozambique), where he was supposed to deal with indigo production. In 1729 he is mentioned as sergeant in the service of the East India Company in Cape Town. Somewhat later he was transferred to the Garrison in Asia, where he died in 1731 (Nationaal Archief 2012; VOC 1727, 1729).

An especially high number of soldiers from the Polish-Lithuanian Commonwealth, who took up service in the Cape Colony in the $18^{\text {th }}$ century, originated from Royal Prussia. Again, the biggest group came from Gdańsk. I shall list here some of those, who stayed in the Colony the longest (year of arrival provided in brackets): Mathias Koch (1712), Jan Raeck (1721), Jan Arentberg (1723), Jan de Pool (1732), Paul Tetz (1737), Efraim Pusman (1737), Jakob Granat (1744), Jan Henrik Winkler (1745), Jan Kaminski (1746), Chistian Steen (1746), Andreas Meyer (1748), Jan Kroll (1750), Jurgen Elgenowski (1751), Peter Emanuel Bem (1752), Jan de Boer (1758), Andreas Dirkze (1758), Karol Freislich (1759), Martin Zinkowski (1764), Jan Daniel Kiepke (1769-1773), Gottlieb Willer (1727), Michiel Gerens (1766), Karol Goor (1770), Peter Langenau (1770), Jan Jakob Kube (1775). The examples of those, who came from the neighbouring city of Elblag are: Jan Knoop (1737), Henrik Teszler (1738), Jan Antony Brits (1740), while Jakob Woleński (1729-1730) 
and Antony Christoffel Kaltenbach (1769) came from other towns of Royal Prussia (Höge 1946: 57, 76, 102, 109, 116, 192, 208, 209, 222, 225, 233, 269, 323, 408, 419-420, 422, 464, 471; Nationaal Archief 2012).

Similarly as in the preceding period, there were also numerous emigrants coming from Ducal Prussia. So, from Königsberg came Mathias Dombrowski (1708), Jan Michiel Krumholect (1728), Friedrich Leitt (1735), Godfried Drosky (1746), Antony Leertouwer (1750), Christian Friedrich Herbst (1752), Carl Friedrich Abel (1757), Johann Christoffel Leeuwner (1765); from Klaipeda: Jakob von Reenen, Martin Melck; from other parts of this region: Johannes Martinus Depner (1735), Jurgen Hendriks (1736), Carl Philipp Miesel (1758), Albrecht Raphael (1759), Johann Heinrich Matthiessen (1765), Peter Henkes (1767), Johann Friedrich Meeding (1776) (Höge 1946: 1, 75, 78, 80, 148, 151, 222, 235, 236, 258, 261, 263, 267, 275, 324, 327; Nationaal Archief 2012).

Many of those listed here settled in the Colony for good and established families. During the entire period considered (1652-1814) this group included roughly 20 emigrants from Royal (Western) Prussia and also roughly 20 from Ducal (Eastern) Prussia (tab. 1). Their descendants entered the local society, and whenever the masculine lineage was preserved, the present-day Afrikaner families still bear their names, such as, for instance, Dirksen, Knoop, Tessenaar, Kroll, Kube, Freislich, Drotsky, van Reenen, Melck, Kromhout, Dippenaar, Raphael, Meeding, Willer, Henkes (“White Pages" 2015).

A significant position in the society of the Cape Colony was attained, in particular, by three emigrants from Ducal Prussia. One of them was Godfried Drotsky. He originated from Königsberg and came to Cape Town in 1746. He might have been a member of the wide and numerous in north-eastern Poland (in Prussia, Masovia, Podlasie) family of Trocki (Trotsky) ("Mapa nazwisk: Trocki" 2007-2008). In 1757 he gained the status of citizen and advanced to the degree of lieutenant in the company of local dragoons. His descendants, who use the name of Drotsky or Drotskie, live in South Africa until today (Höge 1946: 80). Another immigrant from the Duchy of Prussia was Jakob von Renen. He came to the Cape of Good Hope in 1721 as a cadet at the service of the Company. He originated from Klaipeda, and his parents were Daniel and Katharina Elisabeth - maiden name Kroski. In 1725 Jakub acquired the rights of a citizen of the Colony. He died in 1764 as the owner of the property worth 180,000 guilders. Married twice, he had altogether nine children (Höge 1946: 327). One of his sons, also Jacob, was the leader of the Cape Town patriots. He was also one of the richest citizens of the Colony. His sons (grandsons of the emigrant from Klaipeda) continued this tradition. They also participated in a few expeditions into the South African interior and left interesting reports describing their travels (Koch 2004: 109-116, 305). 
Table 1. Settlers of Polish origin, ancestors of the South African families (1652-1814)

\begin{tabular}{|c|c|c|c|}
\hline No. & Name & Origin & Arrival \\
\hline 1 & Jurgen Botkewitz & Warsaw, the capital of Poland & 1676 \\
\hline 2 & Joost Stredon & The Netherlands & 1678 \\
\hline 3 & Johan de Jonker & Królewiec (Königsberg), Ducal Prussia & 1684 \\
\hline 4 & Lourens Campher & Gdańsk (Danzig), Royal Prussia & 1686 \\
\hline 5 & Christoph Grünwald & Królewiec (Königsberg), Ducal Prussia & 1690 \\
\hline 6 & Martin Meckelenburg & Gdańsk (Danzig), Royal Prussia & 1690 \\
\hline 7 & Johann Martinus Kneppel & Gdańsk (Danzig), Royal Prussia & 1694 \\
\hline 8 & Peter Becker & Królewiec (Königsberg), Ducal Prussia & 1695 \\
\hline 9 & Pieter Malmer & Gdańsk (Danzig), Royal Prussia & 1700 \\
\hline 10 & Thomas Eysman & Królewiec (Königsberg), Ducal Prussia & 1704 \\
\hline 11 & Johann Raeck & Gdańsk (Danzig), Royal Prussia & 1721 \\
\hline 12 & Jacob von Renen & Kłajpeda (Memel), Ducal Prussia & 1721 \\
\hline 13 & Gottlieb Willer & Gdańsk (Danzig), Royal Prussia & 1727 \\
\hline 14 & Johann Michael Krumholect & Królewiec (Königsberg), Ducal Prussia & 1728 \\
\hline 15 & Johannes Martinus Depner & Welawa (Welau), Ducal Prussia & 1735 \\
\hline 16 & Friedrich Leitt & Królewiec (Königsberg), Ducal Prussia & 1735 \\
\hline 17 & Ludwik Magetski & The Netherlands & 1735 \\
\hline 18 & Jürgen Hendriks & Pilawa (Pillau), Ducal Prussia & 1736 \\
\hline 19 & Paul Tetz & Gdańsk (Danzig), Royal Prussia & 1737 \\
\hline 20 & Johann Knoop & Elbląg (Elbing), Royal Prussia & 1737 \\
\hline 21 & Heinrich Teszler (Tessenaar) & Elbląg (Elbing), Royal Prussia & 1738 \\
\hline 22 & Christian Steen & Gdańsk (Danzig), Royal Prussia & 1742 \\
\hline 23 & Wilhelm Ferdinand Hooyer & Mitawa (Mitau), Courland & 1744 \\
\hline 24 & Godfried Drosky & Królewiec (Königsberg), Ducal Prussia & 1746 \\
\hline 25 & Martin Melck & Kłajpeda (Memel), Ducal Prussia & 1746 \\
\hline 26 & Andreas Meyer & Gdańsk (Danzig), Royal Prussia & 1748 \\
\hline 27 & Johan Kroll & Gdańsk (Danzig), Royal Prussia & 1750 \\
\hline 28 & Anton Leertouwer & Królewiec (Königsberg), Ducal Prussia & 1750 \\
\hline 29 & Erdman Seydler & Gdańsk (Danzig), Royal Prussia & 1751 \\
\hline 30 & Christian Friedrich Herbst & Królewiec (Königsberg), Ducal Prussia & 1752 \\
\hline 31 & Albrecht Raphael & Welawa (Welau), Ducal Prussia & 1756 \\
\hline 32 & Carl Friedrich Abel & Królewiec (Königsberg), Ducal Prussia & 1757 \\
\hline 33 & Andreas Dirkze (Diksen) & Gdańsk (Danzig), Royal Prussia & 1758 \\
\hline 34 & Carl Philipp Miesel & Pruski Holąd (Preussisch Holland) Ducal Prussia & 1758 \\
\hline 35 & Carolus Augustus Freislich & Gdańsk (Danzig), Royal Prussia & 1759 \\
\hline 36 & Johann Christoffel Leeuwner & Królewiec (Königsberg), Ducal Prussia & 1765 \\
\hline 37 & Johann Heinrich Matthiessen & Królewiec (Königsberg), Ducal Prussia & 1765 \\
\hline
\end{tabular}


Table 1. cont.

\begin{tabular}{lllc}
\hline No. & Name & Origin & Arrival \\
\hline 38 & Michael Gerens & Gdańsk (Danzig), Royal Prussia & 1766 \\
39 & Peter Henkes & Gołdap, Ducal Prussia & 1767 \\
40 & Johann Jürgen Wotsky & Lipawa (Liebau), Courland & 1767 \\
41 & Anton Christoph Kaltenbach & Toruń (Thorn), Royal Prussia & 1769 \\
42 & Carl Gotlieb Goor & Gdańsk (Danzig), Royal Prussia & 1770 \\
43 & Jacob Saul Müller (Mulder) & Rawicz, Greater Poland & 1771 \\
44 & Johann Jacob Kübe & Gdańsk (Danzig), Royal Prussia & 1775 \\
45 & Johann Friedrich Meeding & Finkenstein, Ducal Prussia & 1776 \\
46 & Antony Blisewski & The Netherlands & 1781 \\
47 & Johann Michiel Roos & Kiersity, Ducal Prussia & 1786 \\
48 & Christian Troskie & Gdańsk (Danzig), Royal Prussia & 1784 \\
49 & Johann Heinrich Jankowitz & Mitawa (Mitau), Courland & 1787 \\
50 & Johann Christian Friedrich Gulsen & Gross Datzen, Ducal Prussia & 1788 \\
51 & lgnatius Wereditsky & Poznań, Greater Poland & 1792 \\
52 & Johann Michael Sowietsky & Tarnów, Lesser Poland & 1793 \\
53 & Christian Schönrat (Schoonraad) & Gdańsk (Danzig), Royal Prussia & 1796 \\
54 & Johan Jacob Pansegrau & Grodzyna (Graetz), Royal Prussia & 1803 \\
& & (his father origin) & 1811 \\
55 & Johann Kitschuck (Kitshoff) & North-Eastern Poland & 1811 \\
56 & Johann Latsky & North-Eastern Poland & 1811 \\
57 & Jan Mazurek & Poland (no details) & 1811 \\
58 & Jan Barenski & Poland (no details) & 1811 \\
59 & Jan Chintzak & Poland (no details) & 1811 \\
60 & Lukas Schiskosky & Poland (no details) & 1811 \\
61 & Gabriel Valensky & Poland (no details) & 1811 \\
62 & Jean Kolesky & Warsaw, capital of Poland & 1813 \\
63 & Peter(?) Beirowski & Royal Prussia & 1813 \\
64 & Martin Jewaskiewitz & Poznań, Greater Poland & \\
\hline & & & \\
& & & \\
& & & \\
& &
\end{tabular}

Klaipeda was also the place of origin of Martin Melck. After a short service in the Cape garrison he settled in the Colony. First, he undertook various odd jobs, but later on he established his own brickyard. In 1750 he gained the status of citizen of the Colony and purchased two farms. The census of the subsequent year informs that he owned one horse, 48 cows and 4,000 grapevines. In 1752 he married the widow of his former superior, and when she died, he married for the second time. In 1776 Melck already owned ten farms and their warehouses in Cape Town. In one of the warehouses he would organise secret Lutheran rites, since in the Dutch 
properties the only allowed Christian denomination was the Reformed (Calvinist) church. At that time Melck owned 203 slaves, 170 horses, 1321 cows, 1167 sheep, 106 pigs, and 200,000 grapevines, and he was one of the richest persons in the Colony. From his two marriages he had seven children (Höge 1946: 265-267).

The representatives of the Magetski family, having resided previously in the Netherlands, also came to the Colony. The name of Magetski suggests the Polish or Czech origins of the family. The first of them to come was Jan Ludwig Magetski, born in 1706 in Nijmegen, in the Netherlands. He enrolled in the Company service in 1731 as the artillery gunner on the ship Castor en Pollux (Nationaal Archief 2012). His skills were apparently quickly recognised, for in 1735 he was already the chief steward at the court of the governor in Cape Town. He brought then to the Colony his mother, Chatarine Driessen, and his sister Katharina Maria Magetski. In 1738 Jan Ludwig married Petronela Scheepsdorp. In 1739 their daughter Cornelia Ida was born. The mother and sister of Jan Ludwik married as well. The mother married the main gardener of the Colony, Francois Wijkaart. She died in 1756. The sister married in 1739 Nikolaas van Blerk, this being the beginning of the large South African family of Van Blerk. After the death of van Blerk she married - similarly as her mother - the main gardener of the Colony, Bernard Mullard. She survived also her second husband, and, during the last years of her life, she owned the "Het Roode Hek" farm in the Table Valley. Jan Ludwig Magetski enrolled again on a Company ship in 1742. This time he sailed as a sergeant to Asia. There, in 1751, he was considered lost. His daughter Cornelia Ida married in 1757 in Cape Town Jacob Schouten from Amsterdam, who was a senior officer at the Company service. After the death of her husband she returned to the Netherlands (VOC 1735; Leibbrandt 1906: 746, 761, 765, 769; De Villiers and Pama 1966: 519; Kowalski 2006: 40).

Despite the strong influence of the German culture in Prussia, the emigrants from this region, as well as their descendants, had deeply rooted feelings of connections with Poland and the Polish element. This fact had been observed before, since the wife of Henrik van der Stel, Constantia Abrahamsz, was considered in her environment to be a Pole. This concerned also the Ducal (Eastern) Prussia, which finally severed in 1701 the political ties with the Polish-Lithuanian Commonwealth. Andreas Schults from Iława (Eylau), situated on the territory of Ducal Prussia, who served in the years 1756-1760 in the East India Company, declared that his town of origin is located in Polish Prussia. The same occurred in 1776 in the case of Ertman Hendrik Tiel, originating from the neighbouring town of Ostróda (Osterode) (see Nationaal Archief 2012). The positive attitude towards Poland among the emigrants from Gdańsk and Prussia was observed by the Polish nobleman Teodor Anzelm Dzwonkowski, who served in the years 1788-1793 as a junior officer on the Dutch vessel Zephyr (Kowalski 2012: 284). 


\section{The final period of the Dutch Cape Colony (1778-1814)}

\subsection{The decline of the rule of the East India Company}

Quite an important group of Poles appeared in the Cape Colony in the last years of the rule of the East India Company and also after the termination of this rule, but yet before the formal takeover of the authority regarding the Colony by the British (in 1814) and before the beginning of the mass British colonisation (1820). The decisive role in the generation of this emigration was played by the partitions of the Polish-Lithuanian Commonwealth, the conflicts between the supporters of the Oranje dynasty and the new Dutch Patriots in the Netherlands, the French Revolution, and the Napoleon wars, which followed. New military units appeared in the Cape Colony, originating from various countries: Swiss, German, French and British. Poles also served in those various armies, since, due to the political turmoil of that period, they would get dispersed across the continent and the globe.

The appearance of the new Dutch Patriots party in 1778 in both the Netherlands and in the Cape Land was closely associated with the more general sociopolitical upheaval in Europe. The tensions and conflicts, which resulted there from caused intensification of migratory movements, as well as the movements of the armies. Prussian intervention detachments, along with the deserters from the armies fighting the revolutionary France, appeared in the Netherlands. In this context, Poles would appear, as well. Foreign troops entered also the Cape Colony - initially upon the invitation from the side of the Dutch authorities. This kind of military unit was, in particular, the DeMeurons Regiment, which came to the Colony in January 1783. This was a Swiss mercenary unit, in which soldiers from various European countries served. Among them - Tymoteusz le Bidelt from Warsaw and Henry Jankowicz (Jankowitz) from Courland (Nationaal Archief 2012). The latter settled in the Colony for good (Höge 1946: 182; De Villiers and Pama 1966: 361; Pama 1983: 175).

Soon afterwards, the French Régiment de Pondichéry and the mercenary regiment of the Grand Duke of Luxembourg also came to the Colony. The latter unit included also Blasius Kolichounskij from Piesko (Nationaal Archief 2012). Another foreign military unit that served the Company was Württemberg Regiment, which was stationed in the Cape Colony in the years 1787-1791. This regiment had as soldiers, in particular, Johan Brechlensky from Zbąszyń, Andreas Dombrowsky and Georg Grambau from Gdańsk, Ernst Bohme from Mittau, Ludwig Loncki from Brussels, Laurenty Guerezinski from Poznań, and Wilhelm Landenberger from Königsberg (Nationaal Archief 2012).

Yet, there were still new soldiers from Poland, who would directly get enrolled in the East India Company. Many of them could have been deserters from 
the Prussian or Austrian armies, whose detachments were sent to The Netherlands in order to fight back the revolution. Sources mention first of all Christian Truschke from Gdańsk (1784), Christian Schonrat from Gdańsk (1792), Michiel Sowiecki from Tarnów (1793), and Ignacy Weredycki from Poznań (1793). All four, along with the earlier mentioned Janowitz, married local women, and gave the foundations - except for Weredycki - for the Afrikaner families, existing until today: Jankowitz, Troskie, Schoonraad and Zowitsky (Kowalski 2009; "White Pages" 2015).

One should also mention soldiers originating from the then East Prussia, extended in 1772 by Warmia, which was taken away from Poland. The emigrants from that region included, in particular, Jan Michiel Roos (1786), Jan Christian Gulsen (1788), Johann Gottlieb Welgemoed (1795), Karl Wilhelm Roscheit (1805). They also established families, and their descendants live until now in South Africa. The most numerous of those are the representatives of the Welgemoed family (Höge 1946: 126, 345, 350, 454; “White Pages” 2015).

During the last years of the rule of the East India Company in the Cape Colony there were, however, many more soldiers coming from Poland. In the 1780s the sources mention, in particular, August Richim (1785), Jan Sinowski from Königsberg (1787), and Antony Gładkowski (1786) (Nationaal Archief 2012). Another group of five soldiers, coming from Poland, was brought to the Cape Colony in 1793 on the ship Ceylon: Joseph Podolewski from Warsaw, Jan Kazimierski from Cracow, Jan Czekałowski, Joseph Morzeński from Kraków, and Jan Borkowski (Nationaal Archief 2012). In the very same year, on other vessels, the following soldiers from Poland arrived: Jan Kacper Henryk Hinkel, Jan Gozelon, Antony Chrystka, Anastasius Grzegorzewski, Karl Maciszowski, Stanislaw Wikliniowski, Antony Kamodziski, Karl Drewicki, Antony Kuratowski and Franz Bonk. A year later, on the ship Voorland, came: Dawid Dybnicki from Wyszogród, Jan Jakisz, Franz Narbutt, and Joseph Jaskrański from Cracow. Sources say nothing of their later fate (Nationaal Archief 2012).

Emigration of women from Poland to the Cape Colony was a rare event. It increased only in the second half of the $19^{\text {th }}$ century, along with two colonisation actions, organised by the British authorities. Until the end of the $18^{\text {th }}$ century only one such case was recorded. It concerned Barbara Fuhrmann from Gdańsk. She married in the Colony a bookbinder, Johann Christian Ritter, born in 1755. She died childless in 1813 (Höge 1946: 339, 489).

In July of 1780 Anthonie Blisewski (Bliesefskie) came to the Colony. Somewhat earlier, in the years 1777-1779 he was a paramedic during the cruises on the route Amsterdam-Batavia-Amsterdam. He was born in 1756 and originated from Heusden in the Netherlands, but the name suggests that he was a descendant of an emigrant from Poland (if it was not himself who emigrated). After 
having come to Cape Town, Blisewski became the head surgeon on the ship Sterrenschans, which was permanently stationed in this harbour. Soon, he established family and settled in Cape Town for good. He died in 1798 at the age of 42. From two wives he had three sons (Henrik, Jan, Anthonie), and at least three daughters (Anna, Maria, Antonina). The fate of the sons is not known, while daughters married local citizens. In 1791 Pieter Cornelis Blisewski came to Cape Town as a gunsmith on board of the Zwaan ship. It can be supposed that he was a brother or cousin of Anthonie. Two years later he perished somewhere in Asia (De Villiers and Pama 1966: 622; Kowalski 2006: 41; Nationaal Archief 2012; Dutch Reformed Church Registers 1660-1970).

\subsection{The journey of Teodor Anzelm Dzwonkowski}

Many soldiers wished to settle in the Colony. This, however, was not a simple task. Teodor Anzelm Dzwonkowski, who served in the years 1788-1793 on the Dutch vessel Zephir, learned this very well. Dzwonkowski participated in the expedition, which was an inspection of the Dutch properties in the Eastern hemisphere, commissioned by the stadhouder Wilhelm V. During this expedition he visited the Cape Colony twice. While on the cruise to India, he spent almost half a year there (between May and October 1789), and on the way back - an even longer period (between August 1792 and March 1793) (see Cunningham 1975; Dzwonkowski 1985). Dzwonkowski left a journal, in which he described the experiences from the journey. Owing to his literary talents we can get to know the circumstances of taking up service by Poles in the Dutch colonial forces. One can also learn the realities of the service and the observations made while being employed there. Due to the two several months long stays of Dzwonkowski in the Cape Colony we deal with a unique report by a Pole, who went there as a soldier in the Dutch service.

Teodor Anzelm Dzwonkowski was born in 1764 in the village of Przytuły in the vicinity of Ostrołęka, where his parents owned a landed estate. He lost his parents early, started his education in Łomża, but then moved to Warsaw, where he continued his studies and worked at the same time. Limited income, coupled with abundant social life, brought financial trouble. In order to get away from this situation, he left Warsaw, and in 1783 enrolled in Prussian hussars. Conditions of the service did not suit him well, and after two years of stationing in Działdowo he obtained an official release and went by sea from Königsberg to Amsterdam. This was the period of struggle in the Netherlands between the partisans of the Oranje house and the New Dutch Patriots. The struggle ended with the victory of the former, the intervention of the Prussian army being decisive in this regard. Dzwonkowski hoped that the new situation would allow him to easily find a post in the Dutch military forces, then under 
reconstruction by the ruler. After three months that he spent in Amsterdam, he finally decided to take up service as a corporal on the ship Zephyr, which was to start off soon for the cruise towards South Africa and India (Dzwonkowski 1985: 51-60).

When he enlisted, Dzwonkowski hid his Polish origins. He would pretend to be a Hungarian, and used the name of Pregonius (from his coat-of-arms, Przegonia). He did this out of fear of discrimination from the side of the superiors and other soldiers. The majority of the crews of Dutch vessels were constituted by Germans, and Dzwonkowski had experienced already during his service in the Prussian army numerous annoyances from their side, related to his Polish origins. Poles were being accused of "excess in Polish clothing habits, indecency in shaving of the head, fanatic attitudes, superstitions, tyranny in subordination" (Dzwonkowski 1985: 60, 74). It cannot be excluded that other Poles, who would enter Dutch service, also concealed their nationality. This might mean that the number of Poles in the colonial Dutch forces could have been higher than indicated by the official registers.

Dzwonkowski started his first stay in the Cape Colony from the search for Poles living there. Although this was not simple, he befriended after some time the emigrants from Gdańsk and Prussia, who had settled in the Colony long before. It can be supposed that these were some of the persons mentioned in the report before. Owing to these acquaintances he could get introduced into the social life of Cape Town and collect interesting pieces of information on the country. When his ship was getting ready to sail on farther, the new friends cordially bid him farewell, and visited him on the ship several times before the anchor was raised. It must be added that the local relations and climate were so much to the liking of Dzwonkowski that - just like his predecessors - he started the attempts of settling in the Colony. This kind of privilege (the status of a settler) could be gained at that time only by a soldier with a sufficiently long - of at least seven years - service period in the East India Company. The efforts of the Polish nobleman were doomed to fail, the more so as the expedition, in which he participated, was not undertaken under the auspices of the Company (Dzwonkowski 1985: 66-72).

We owe to Dzwonkowski interesting observations, concerning the realities of South Africa. These observations deal with the organisation of the socio-economic life, and they include also critical opinions on the monopolies and limitations in many domains of economy. The author of the journal notes that the sole products of the country are: wine, ostrich feathers, raw hides of the livestock and wild animals, turtle and snail shells, as well as cod liver oil. At the same time, Dzwonkowski notices lack of crafts and the associated necessity of bringing in numerous products from Europe (Dzwonkowski 1985: 66-72). 
Further, Dzwonkowski forwards also interesting remarks, concerning local society. He notices that the inhabitants of Cape Town like entertainment and enjoy quite lax habits. Outside of town he describes farmers (to whom he refers in Polish, but with a distinct linkage to the local tradition, using, namely the Polish dialect word "gbur," quite close to "boer"). The plantations of these farmers are often so vast that they require owning hundreds of slaves for working them. He was under the impression of the exercises of the local levy in mass, composed of the representatives of the young, ready to defend their homeland, should the need arise. Side by side with the societies of European origin, he describes also the Khoi-Khoi, Khoi-San, and Bantu peoples. He emphasises the differences between them, and even the differences between the local Bantu and the black Africans that he had known before. Concerning Khoi-Khoi, Dzwonkowski notices the characteristic features of their physiognomy and anatomy, including the yellowish colour of their skin, extremely flat faces and noses, shortness, as well as steatopygia and swayback. Regarding women of this people he pays attention to the so-called Hottentot apron. He notes also the characteristic click language of the representatives of these tribes, underlining that "their speech is indescribable, for they understand each other only by smacking and clicking their tongues and lips" (Dzwonkowski 1985: 66-72).

During his further journey, in Asia, Dzwonkowski succeeded in meeting two other Polish noblemen, who had gotten employed in the East India Company. Both climbed high in the colonial hierarchy. One of them was named Ostrowski and left the Polish-Lithuanian Commonwealth as a boy during the Bar Confederation (a military movement at the turn of the 1770s, aiming to prevent the loss of independence of Poland). In the Netherlands he was enlisted on a Company ship. When Dzwonkowski met him, he was already the commander of the island of Ambon, situated in the Moluccas Islands archipelago. Dzwonkowski encountered the second compatriot, named Dunin, in 1792 in the town of Bantam on Java. Dunin had already been a soldier in Poland, but as he could not advance for a long time, he decided to seek his fortune in the Netherlands. There he took part in the civil war of Oranjes and Patriots. After the civil war ended he enrolled as a junior officer at the East India Company, where, during four years of service he advanced to the degree of colonel. This information, found in Dzwonkowski's journal, finds confirmation in other reports and in Dutch archives. Captain Ostrowski is mentioned as the commander of Ambon island yet in 1796 (Heeres 1908: 284, 286). On the other hand, Walenty August Dunin from Warsaw entered the Company service in 1788, that is - at the same time as Dzwonkowski did. In the course of his journey to Asia he spent two and a half months (February-April 1789) in Cape Town (Nationaal Archief 2012). 
Anzelm Dzwonkowski also advanced during his five-year service in the detachment of soldiers, constituting the guards of the Zephyr ship. Initially, he was a corporal, but before coming to India he was nominated sergeant, since his predecessor died of scurvy. Not much later the commander of the detachment perished in a skirmish with pirates. Dzwonkowski took his position, advancing, at the same time, to the rank of an officer (Dzwonkowski 1985: 74, 109).

\subsection{Zowitsche, Werditsche, and Stephanos}

In more or less the same time as Dzwonkowski, two other, already mentioned Poles arrived: Jan Sowiecki (Sowietsky) and Ignacy Weredycki (Ignatius Werreditsky). In distinction from Dzwonkowski, they settled in the Cape Colony permanently. Before they came to the Cape they most probably had been involved in wars in Europe. It is known that Weredycki participated in the fighting between the Patriots and the supporters of the Oranjes in the Netherlands (Teenstra 1943: 126-127). When he settled in the Cape Colony, he gave the place of his origin as "Prussian Poland." It might be supposed, then, that he came to the Netherlands as a soldier of the Prussian army, incorporated into it - like many Poles - on the territories annexed in 1772 by Prussia. The Prussian army entered the Netherlands in 1787, giving the victory to the supporters of the house of Oranje-Nassau. The garrison of 4000 Prussian soldiers remained in the country. Most probably, Weredycki did not find it suitable to serve as a Prussian soldier and an occupant in the Netherlands. We can suppose that he defected and joined the East India Company. We know for sure that he came to South Africa aboard the vessel Enkhuizer Maagd in 1793, along with Jan Michiel Sowiecki and other soldiers, originating from various European countries, including Poland (Nationaal Archief 2012). It is highly probable that their fates had been similar before they came to South Africa (Kowalski 2009: 149-150).

Starting most probably with 1795 , both Poles served in the artillery company in Cape Town, commanded by Major Georg Conrad Küchler (Höge 1946: 457). In the very same year, as a result of the British invasion and the battle of Muizenberg (August $7^{\text {th }}, 1795$ ), the Cape Colony found itself under British occupation. Despite this fact, both Poles remained in the Colony. In 1798 Jan Sowiecki married a local woman, Johanna Katharina Heyst. The couple had several children, but by 1809 only two sons were still alive: Matias Burgard (born in 1799) and Godfried Frederic (born in 1802). Sowiecki's wife died as well. We do not know anything about the private life of Weredycki during these years - only that until 1807 he remained single (Höge 1946: 143-144, 401; De Villiers and Pama 1966: 911; Kowalski 2009: 149).

A bit earlier, essential political changes took place. The Cape Colony had been under British occupation until the year 1802, when, by virtue of the Amiens 
peace, it was handed over to the Republic of Batavia. The French and Batavian military troops came to the Colony with numerous Poles serving in these detachments (Żukowski 1994: 67-68). Sowietski and Weredycki started their service anew in the artillery company in Cape Town. This lasted until 1806, when the consecutive British landing operation took place. The Batavian-French forces, commanded by the Dutch general Jan Willem Janssens, were defeated on January $8^{\text {th }}, 1806$, in the battle of Blaauwberg (Leśniewski 2008: 122-124).

Sowiecki and Weredycki escaped from Cape Town in the company of the Hungarian (his name may have been originally written as Ferenc Maros). We know this owing to the testimony of the latter, which he made in November 1815 to the local marshal in Uitenhage in the eastern part of the Cape Colony. ${ }^{3}$ The Hungarian testified that after the defeat of the Batavian forces he fled with the Poles to Swellendam, situated $220 \mathrm{~km}$ to the East of Cape Town. He did not know what happened to his companions later on, since they took separate routes thereafter. The Hungarian, with his cart, moved farther inland, and since then stayed on the farms of various people. Ultimately, he settled in Tarka, a town within the eastern borderland of the Colony (Leibbrandt 1902: 272-273).

We know from other sources that Jan Sowiecki also travelled eastwards. He found refuge, along with his two sons, on the farm owned by Konrad de Buys, famous South African trekboer. This farm was located in Couca, on the area of Langkloof valley. Sowiecki most probably became close with the family de Buys, since he married his daughter Elisabeth (her mother was a coloured woman Maria van der Horst). Three children were born to this couple: Jan Michael, Katharina Gertrud, and Maria Magdalena (Orphan Chamber 1809; Crampton 2004; Kowalski 2009; De Buys 2010; “Sowietsky, Johan Michael..."). Persons in South Africa, whose contemporary names are Zowitsky, Zowitsche and Zovitskey, are, most probably, the descendants of Jan Sowietski and his children from his two marriages.

After the flight from Cape Town, Ignacy Weredycki did not move as far as Jan Sowiecki did. In 1807 he married a 48-year-old widow Joanna Wilhelmina Beukes in Stellenbosch. After her death he married for the second time, a woman called Maryna Jakubina Cordier (Cortje). The marriage ceremony took place on November $17^{\text {th }}, 1823$ in Swellendam, and the couple resided in the vicinity of the Potberg mountains. In the year 1825 they visited the Caledon Bath resort. According to M.D. Teenstra (1943), who met them there, the couple were friendly and highly religious. During the last years of his life, Weredycki was mentioned in the documents under the names of Werdetskij or Werditsche. He died in 1847. No source exist on his potential descendants (Kowalski 2009: 150).

\footnotetext{
${ }^{3}$ The testimony was connected with the revolt of 1815 , called Slagtersnek (Slachter's Nek).
} 
More or less in the same time with Dzwonkowski, Sowiecki or Weredycki, an adventurer arrived at the Cape Colony who gained fame under the nickname of Stephanos. His true name remains a mystery, but it is supposed that he originated from Poland. Initially, he was most probably a soldier in one of the mercenary regiments, stationed at the end of the $18^{\text {th }}$ century in the Colony. Around the year 1800 he was accused of trickery and money forgery, which forced him to seek refuge within the territories to the North of the area of the Colony. Under the influence of J.J. Kicherer, the representative of the London Missionary Society, he decided to undertake missionary work. He invented his own religion, which linked together the elements of Christianity, Islam, Judaism, and African indigenous religions. He designed special rites for this new religion, and announced himself to be a prophet of the new faith. His influence extended over the tribes of Orlam, Korana and Griqua, living at the Gariep (Oranie) river. These tribes have appeared due to mixing of the European settlers with the local Khoi-Khoi (Hottentot) peoples. Stephanos was initially adopted into the community living under the leadership of Cornelius Kok. He married a local woman. Under the pretence of spiritual experiences he also maintained relations with other women from the tribe. When the false religion was unmasked, Stephanos reverted to Christianity. Then, the leader of the neighbouring tribe, Jager Afrikaner, fell under his spiritual influence. The alliance of the two individuals made it possible to defeat the British punitive expedition, commanded by Colonel Gordon. After this event, Stephanos disappeared. He was most probably killed by the members of the Nama tribe (Barrow 1806: 423-427; Chidester 1994: 3-5; Penn 2005: 250-254; Du Preez 2008: 20-25).

Side by side with Weredycki and Sowiecki, there were also other Poles who served in the Batavian and French armies stationed in the Colony in the years 1803-1806. One of the units of these armies was the $9^{\text {th }}$ fusilier battalion. Many of its soldiers' lives ended on African soil, some of them shot for defecting. Five Polish deserters from the $9^{\text {th }}$ fusilier battalion were never found, while traces of their presence were supposedly tracked to the farthest corners of South Africa (Żukowski 1994: 67-68).

\subsection{Poles in the British occupation forces}

The subsequent, particularly numerous, group of soldiers, originating from Poland, appeared in the British occupation forces (1806-1814). Possibly, the first of them served in the detachments, which took control of the Colony in January 1806. There are more information concerning Poles, who were soldiers in the $4^{\text {th }}$ Battalion of the $60^{\text {th }}$ Infantry Regiment. This unit was stationed at the Cape between July 1806 and March 1808. They came to the Cape from the Caribbean (Jamaica). The Poles, who served there, were taken prisoner by the British on Haiti. 
The payrolls of this battalion contain Polish (or Slavonic) sounding names such as: Joseph Popelka, Martin Linkowitz, Martin Dousky, John Shubaneck, John Nowikow, Anton Salesky, Casimir Kufsar, Stanislaus Jasiba, John Schowacke, John Slowoda (Kowalski 2009: 160).

An important group of Poles arrived at the Cape in September 1811 on board of the British navy ship Lion. These were the soldiers serving in the $1^{\text {st }}$ battalion of the $60^{\text {th }}$ Infantry Regiment. This unit was also initially stationed in the Caribbean, but a couple of months before coming to Africa, went to England for complementary recruitment. Many of its Polish soldiers had served before in the Dutch or French troops. Some of them were recruited by the British in 1803 among the prisoners of war captured in Haiti. They were, in particular, the former soldiers of the Polish so-called Danube Legion, formally paid for service by the Republic of Batavia. In 1802 the Danube Legion was transformed into the $1^{\text {st }}$ Polish Half-Brigade and sent to Haiti to put down the anti-French uprising. The very same fate befell the $2^{\text {nd }}$ Polish Half-Brigade, formed out of the Polish Legion in Italy. Approximately 80\% (out of 5000 ) of the soldiers from these units were killed in action or died of yellow fever. The majority of those that survived, surrendered to the British and were transported to Jamaica. At the end of 1803, after two months of imprisonment, almost all privates and a large proportion of the junior officers were incorporated into the British detachments, mainly in the $60^{\text {th }}$ Infantry Regiment. Others shared a similar fate in 1809 in Holland, when the British landing operation took the island of Walcheren for a period of time. Poles served there in several of Napoleon's detachments, composed mainly of the fugitives from the Prussian army. When faced with the prospective of the hardships of imprisonment in England, many Poles chose service in the foreign regiments of the British army. Polish prisoners of war, taken in Italy and in Spain, were also frequently enlisted in British troops (Kowalski 2009: 152).

Owing to this recruitment process, Poles constituted in the $1^{\text {st }}$ Battalion of the $60^{\text {th }}$ Infantry Regiment, stationed at the Cape in the years 1811-1818, at least 20\% (roughly 200 persons) of the total number of soldiers. Smaller groups of Poles would also serve in other units, e.g. in the Royal Garrison Company. Altogether, Poles accounted for at least $10 \%$ of the total British troops at that time in the Cape Colony. Based on the agreement, signed by the rulers of Poland and England in 1814, Polish soldiers were to be released from the service in the British army. Yet, the British did not hurry at all to implement the agreement. The encouragement came from the end of the war (1815) and the difficult financial situation of the army. Polish soldiers, stationed at the Cape, started to be released at the end of 1816. An interesting occurance could be the visit of Polish captain Karol Fryderyk Piątkowski, who, on his way back from St. Helen to Europe, stopped for 
a while in Cape Town (Kowalski 2009: 152-153). Some 40 Polish soldiers, most of them released from the $60^{\text {th }}$ Infantry Regiment, obtained the consent to settle in the Colony after the release. From among them, the biggest traces were left by: Jan Lacki (Latsky), Jan Kiczuk (Kitshoff), Jan Koleski (Kolesky, Coleske), Martin Iwaszkiewicz (Jewaskiewitz), Jan Mazurek (Masureik, Masureth), Jan Barenski (Barensche), Jan Czynszak (Chintzak), Lukas Szyszkowski (Schiskosky), Stanislaw Bajerski, and Gabriel Waleński (Valensky). It is also possible that this group included the man called Beirowski, who appeared more or less at the same time in the Colony, and may account for the family that exists until today (Kowalski 2009: 153-158). The majority of the soldiers mentioned above established families, which were the beginnings of the present-day Afrikaner families. The largest of these include Kitshoff, Latsky, Jewaskiewitz, Kolesky, Masureik, Barensche, Beirowski (Kowalski 2009: 153-158; “White Pages" 2015).

The remaining soldiers do not appear in the South African sources later on. P. Philips (1979) lists the following persons, having Polish sounding names, who were not represented above, those persons having been released from the British forces and having obtained the consent to stay in the Colony: Jacob Bankofsky, Carl Bernicky, Ignatius Grodeck, Joseph Jablonsky, Ignatz Jakuloff, Joseph Jasheck, Jacob Jourisky, Christian Kinski, Matts Krobka, John Kusma, John Laskosky, Paul Lenezk, Jacob Lietsoek, Jno. Lucovitz, Stephan Mollack, F. Nevosattic, Mattew Procuskey, Joseph Rodrilingsky, Joseph Roscheck, Anthony Roshneck, John Schewerisky, John Schoevensky, Ignatz Schuska, John Schastack, Thomas Sorofsko, John Stepinsky, John Trabash, Joseph Washinaski, J. Wingolofsky, Vincent Zewasinsky, Michael Zitzack (Kowalski 2009). One can also add two names, known from other sources: John Markosky and Ignatius Schalek ("Retired Soldiers...").

Among those Poles, who left the biggest traces in the sources, one can indicate Jan Lacki (Latsky). He was born most probably in 1792 in this part of the Polish-Lithuanian Commonwealth, which was incorporated by Prussia. Some sources suggest Lithuania, which might imply the District of Białystok of the then New East Prussia. His parents were Michał and Anna. He was enrolled in the British $60^{\text {th }}$ Infantry Regiment in 1810, that is - at the age of 18 . He was possibly a soldier of one of the Napoleon's regiments, defending Holland, and it is there that he was most probably taken prisoner in 1809 by the British. The legend, repeated in the family, says that in 1812 he took part in the Muscovite campaign of Napoleon and saw Moscow burning. Supposedly he fought in a Cossack detachment against Napoleon. Later on, according to the family legend, he would take part in the battle of Waterloo, as a soldier of the Prussian army, commanded by general Blücher (Żukowski 1994: 106; Van Rensburg 1999: 149). The family story almost certainly magnifies the Napoleon-related 
episode of his life, since in 1810 he was already a soldier of the $60^{\text {th }}$ Infantry Regiment, and since September 1811 he was in South Africa (having come there together with other soldiers of his battalion on the ship Lion). In 1817 (on January $13^{\text {th }}$ ) he was allowed to settle in the Colony. At the beginning, he did not fare well. In 1821 he came without any means of upkeep to Cape Town. Luckily, he found a job in the Paarl as a stableman at a local physician. On June $2^{\text {nd }}, 1826$ he married Lucya Gloudina Buys, in Worcester and in the respective document he is mentioned as a citizen of the town of Beaufort (his name written down as "Laatsche"). The couple had three daughters and two sons. In 1827 Lacki bought roughly 6000 hectares of land in the Karoo and established the farm "Celeryfontein" near to the present day Carnarvon, becoming one of the pioneers of the European farming development in the Great Karoo. He died on December $18^{\text {th }}, 1866$, on his farm. Numerous descendants of Jan Lacki live nowadays in South Africa, bearing the name Latsky (Van Rensburg 1999: 149; Kowalski 2009: 155-156; “White Pages” 2015).

The life histories and the achievements of the progeny of Polish settlers are quite well known as well. Thus, among the descendants of Jan Lacki (Latsky) we can mention, in particular, Luisa "Lulu" Latsky (1901-1980), biologist and writer, who wrote in Afrikaans, and was the very first woman, having obtained a doctoral degree in South Africa; Peter Sterrenberg Latsky (1903-1991), the clergyman of the Reformed Church (Nederduitse Gereformeerde Kerk), for many years the vicar of the prestigious parish of St. Stephan in Cape Town (Luisa's brother), or Johan Michael Latsky (1905-1981), outstanding South African dietary specialist (“Latsky, Johan...;" “Latsky, Luisa...;" Zöllner 1991). Another settler from Poland, Jan Kitshoff (1781-1854), was among the builders of the town of Piketberg. His descendants gained prominent positions in the South African society, among them: Michiel H. C. Kitshoff (1915-1990), the genealogist of the kin, Johannes Jacobus Kitshoff (1918-2004), who, in the years 1972-1988 was the president of the Industrial Development Corporation, Michiel C. S. Kitshoff (born in 1932), a Protestant priest, professor of theology, or, more recently, two rugby players - Rohan Kitshoff (born in 1985) and Steven Kitshoff (born in 1992) (Kitshoff and Lombard 1984; Kitshoff and Pansegrouw 2012; "Kitshoff, Rohan...;" "Kitshoff, Steven..."). One can find similar examples among the descendants of other settlers having come from Poland during the entire period considered in this article.

In 1814 the Cape Colony became in formal terms a part of the British Empire (while being under British occupation since 1806). This, however, did not hamper the inflow of immigrants from Poland. In the majority of cases they also melted into the Afrikaner society. An especially important group came during the decades of 1850s, 1860s and 1870s from the county of Babimost, which was 
a part of the Grand Duchy of Poznań, ruled by the king of Prussia. Polish settlers would come in entire families, these families bearing the names of Ankiewicz, Barański, Hemfling, Lis, Mendelski, Piwecki, Szukała, Waberski, Wejmann, and Wojciechowski. The ancestors of yet other South African families of Polish roots came from different parts of Poland, namely Bogacki (Abagostus, Aproskie), Choromanski, Czapiewski, Dobrowski, Dubiel, Prozesky, Gregorowski, Juritz, Kokowski (Hohowsky), Robeck, Skorbinski, Skowronek. Many of these names can still be encountered in South Africa nowadays (see Schmidt 1955: 356, 368, 378, 386; Pama 1983: 100, 103, 156, 176, 257, 362; "Polish settlers in South Africa...;" "White Pages" 2015). An important group of Poles took also part in the Boer War (1899-1902). Captain Leon Pokrowski, who died fighting on the side of Boers, became a hero of this war (Leśniewski 2001: 148-149).

The families of the emigrants, coming to South Africa in the $20^{\text {th }}$ century, did not assimilate as well in the local society as in the case of their predecessors. This applies in particular to the emigrants from the period of World War II, and from the later years. They constitute the basis for the Polish organisations, functioning today in the Republic of South Africa.

\section{Summary}

Emigrants from Poland (or, more broadly, from the Polish-Lithuanian Commonwealth) were coming to the Colony over the entire period of the Dutch colonisation of South Africa. Intensification of this process coincides with two time instances: the turn of the $18^{\text {th }}$ century and the turn of the $19^{\text {th }}$ century. Intensification of migration in the first of these periods could be associated with the decline of the colonial efforts of the Baltic dukes of the Commonwealth (the ones of Courland and of Prussia), and with the phasing out of the maritime policy of king Jan III Sobieski, which was largely linked to the strength of Gdańsk as harbouring city. The volunteers from Poland started then, most probably, to seek employment in the colonial undertakings of the Netherlands. The increased inflow of emigrants at that time was also the consequence of the intensification of the settling action by the authorities of the Colony. A factor that was conducive to the presence of Poles among the soldiers and the settlers could be constituted by the Polish connections of two consecutive governors of the Cape Colony, Simon and Willem Adrian van der Stel.

Intensification of migrations in the second period mentioned is clearly associated with the political turmoil and the wars, related to the partitions of the Polish-Lithuanian Commonwealth, the struggle between the partisans of the Oranje-Nassau house and the New Dutch Patriots in the Netherlands, the French 
Revolution, and the Napoleon's wars. Poland was occupied then by the foreign forces, which caused that Poles would arrive in the Cape Colony as the soldiers of fortune under various banners. In very frequent cases they would have had experience in the Prussian, Austrian or Napoleon's army, from where, owing to desertion or being taken prisoner of war, they would join the Dutch, Swiss, French, German, or British troops, stationed in the Cape Colony.

Without a detailed genealogical analysis one can hardly estimate the percentage share of Poles among the ancestors of the present-day Afrikaners. Most of the emigrants from Poland, especially those bearing Germanic names, or those originating from Polish Prussia, were classified by the scholars in the German group. This significantly limited the number of settlers that could be considered Poles. A quite superficial estimate of the author allows for the supposition that until 1795 some 800 Germans and 50 Poles came to the Colony, whose descendants entered the local society. If the share of Germans is estimated at 27\% (Greeff 2007) to 37\% (Heese 1971) of the ancestors of the contemporary Afrikaners, then Poles must have constituted between 1 and $2 \%$. This share was certainly preserved in the $19^{\text {th }}$ century, owing to the waves of settlers from Poland at the beginning and in the middle of that century.

Poles were very often involved in the pioneering undertakings within the far-off fringes of the Colony. Jan Liske took part in the expedition to Namaqualand, Michiel Kowalski and four other emigrants from Poland - in the expedition to Cobuquas people, Stephanos gained fame as a humbug and false missionary among the Nama and Griqua peoples, Christian Truschke and Jan Michiel Sowiecki settled the eastern borderland of the Colony (Sowiecki remained in close relations with the Boer pioneer and rebel Conraad de Buys) and Jan Latsky became the pioneer of the European colonisation of the High Karoo. This concerned also the later Polish settlers - even those from the second half of the $19^{\text {th }}$ century - like, for instance, Ankiewicz, Mendelski, Szukała, Waberski - of whom many settled within the eastern borderland of the Colony in the British Caffraria. In an indirect manner the participation of Poles in the extension of the boundaries of the Colony is perceived by R. Shell in the article "The Forgotten Factor in Cape Colonial Frontier Expansion, 1658 to 1817." In his opinion, "all we may conclude is that it was the Cowalskys of this world rather than the Van der Merwes who opened up the frontier in this early period." Shell, however, seems unaware of the Polish origins of Michiel Kowalski and his compatriots, and considers them to be the representatives of the "Teutonic phalanx" (Shell 2005: 24).

Many other foreign scholars, dealing with the history of South Africa, also do not notice Polish origins as part of the emigrants, coming from Poland. This is surprising, since there are various sources, which provide information on 
the contribution of Poles to the development of the foundations for the Cape Colony. Lady Anna Barnard remarks in one of her letters, written in the years 1797-1801 in Cape Town, that "The early settlers, though under Dutch rule, were not wholly Dutch, but were made up also of Flemings, Germans, Poles, and Portuguese, mostly of a low class" (Barnard 1901: 40). Similar observations were forwarded by Sir John Barrow (1801) during his trip across South Africa in the years 1797-1798, this view being also maintained by the $20^{\text {th }}$ century author, Simon A. de Villiers (1971). Perhaps an influence on the opinions of these authors has been exerted by the particularly large group of soldiers, who stayed and settled in the Colony at the turn of the $19^{\text {th }}$ century. This, however, does not change the fact that immigration from Poland, even though with a lower intensity (a comparable intensity being observed only in the years 1679-1707), constituted a permanent phenomenon in South Africa. It is highly probable that in no other part of the New World, at the time here considered - that is: before the mass migrations of the $19^{\text {th }}$ and $20^{\text {th }}$ centuries - the contribution of Poles to the development of the overseas territories and in the formation of new societies was so significant.

\section{Bibliography}

Barnard, A. 1901. South Africa a Century Ago. Letters Written From the Cape of Good Hope (1797-1801). London: Smith, Elder \& Co.

Barrow, J. 1801. An Account of Travels Into the Interior of Southern Africa in the Years 1797 and 1798. London: A. Strahan, Printers-Street.

1806. A Voyage to Cochinchina, in the Years 1792 and 1793: To Which Is Annexed an Account of a Journey Made in the Years 1801 and 1802, To the Residence of the Chief of the Booshuana Nation. London: T. Cadell and W. Davies.

Buys, L.A. de. 2010. De Buys and Dodgson: A Walk Through Time, manuscript. 18 Apr. 2014. $<$ www.scribd.com/doc/15507310/32/Thirteenth-Generation>.

Chidester, D. 1994. Authentic Forgery and Forging Authenticity: Comparative Religion in South Africa. Cape Town: University of Cape Town.

Crampton, H. 2004. The Sunburnt Queen: A True Story. Johannesburg: Jacana Media.

Cunningham, A.M. 1975. Guide to the Archives and Papers. Johannesburg: University of the Witwatersrand.

Dutch Reformed Church Registers. 1660-1970. Index and images, FamilySearch. 18 Apr. 2014. <www.familysearch.org/search/collection/1478678>.

Dzwonkowski, T.A. 1985. Pamiętniki: czyli pamiątka po ojcu dla Józefy z Dzwonkowskich Komornickiej. Warszawa: Państwowy Instytut Wydawniczy [elaborated by Stanisław and Tomasz Komornicki from the manuscript].

Gelder R. van. 1997. Het Oost-Indisch avontuur: Duitsers in dienst van de voc (1600-1800). Nijmegen: Socialistiese Uitgeverij Nijmegen. 
2003. Naporra's omweg: het leven van een VOC-matroos (1731-1793). Amsterdam: Atlas.

Greeff, J.M. 2007. “Deconstructing Jaco: Genetic Heritage of an Afrikaner." Annals of Human Genetics 71(5): 674-688.

Heeres, J.E. 1908. "Eene Engelsche lezing omtrent de verovering van Banda en Ambon in 1796 en omtrent den toestand dier eilandgroepen op het eind der achttiende eeuw." Bijdragen tot de taal-, land-en volkenkunde van Nederlandsch-Indië 60: 249-368.

Heese, J.A. 1971. Die herkoms van die Afrikaner 1657-1867. Cape Town: A.A. Balkema.

Heese, J.A., and Lombard R.T.J. 1986-2008. South African Genealogies. Stellenbosch: Die Genealogiese Instituut van Suid -Afrika (GISA).

Höge, J. 1946. Personalia of the Germans at the Cape. 1652-1806. Pretoria: Archives Yearbook for South African History.

Kitshoff, M.H.C., and R.T.J. Lombard. 1984. Kitshoff: Die nageslag van Johannes Ketshuck. Pretoria: Raad vir Geesteswetenskaplike Navorsing.

Kitshoff, M.H.C., and C.M. Pansegrouw. 2012. Kitshoff: Die nageslag van Johannes Ketshuk. Vishoek: manuscript

“Kitshoff, Rohan." Wikipedia. 18 Apr. 2014. <http://en.wikipedia.org/wiki/Rohan_Kitshoff>.

“Kitshoff, Steven." Wikipedia. 18 Apr. 2014. <http://en.wikipedia.org/wiki/Steven_Kitshoff>.

Koch, J. 2004. Historia literatury południowoafrykańskiej: XVII-XIX wiek. Warszawa: Dialog.

Kowalski, M. 2006. "Polish Boer Families." Familia: Quarterly Journal of the Genealogical Society of South Africa 43(2): 38-46.

2009. "Polish Soldier-immigrants to South Africa in the Period of French Revolution and the Napoleonic Wars (1789-1815)." Familia: Quarterly Journal of the Genealogical Society of South Africa 46(3): 147-164.

2012. "Immigrants from the Polish-Lithuanian Commonwealth in the Early Stages of European Colonization of the Cape Colony." Geographia Polonica 85(3): 55-76.

“Latsky, Johan Michael." 1987. Dictionary of South African Biography 5. Cape Town: Human Sciences Research Council.

“Latsky, Luiza." 1995. New Dictionary of South African Biography 1. Cape Town: Human Sciences Research Council.

Leibbrandt, H.C.V. 1897a. "Riebeeck's Journal, \&c., Dec. 1651-May 1662, 1." Precis of the Archives of the Cape of Good Hope 5. Cape Town: W.A. Richards \& Sons, Government Printers.

1897b. "Riebeeck's journal, \&c., Dec. 1651-May 1662, 3." Precis of the archives of the Cape of Good Hope 7. Cape Town: W.A. Richards \& Sons, Government Printers.

. 1902. The Rebellion of 1815, Generally Known as Slachters Nek: A Complete Collection of All the Papers Connected with the Trial of the Accused; with Many Important Annexures. Cape Town: J. C. Juta \& Company.

. 1906. "Requesten (Memorials) 1715-1806, 2." Precis of the Archives of the Cape of Good Hope 17. Cape Town: W.A. Richards \& sons, Government Printers.

Leśniewski, M. 2001. Wojna burska 1899-1902: geneza, przebieg i międzynarodowe uwarunkowania. Warszawa: Wydaw. Naukowe Semper.

. 2008. Afrykanie, Burowie, Brytyjczycy: studium wzajemnych relacji 1795 -1854. Warszawa: Bel Studio.

Lichtenstein, H. 1928. Travels in Southern Africa, in the Years 1803, 1804, 1805 and 1806. Cape Town: The Van Riebeeck Society. 
“Mapa nazwisk: Trocki.” 2007-2008. Online Social Networking. Hamburg. 18 Apr. 2014. <www.moikrewni.pl/mapa/kompletny/trocki.html>.

Mentzel, O.F. 1921. A Geographical and Topographical Description of the Cape of Good Hope 1. Cape Town: Van Riebeeck Society.

Nationaal Archief. 2012. Scheepssoldijboeken van de Verenigde Oost-Indische Compagnie. Den Haag: Nationaal Archief. 21 May 2001. <http://vocopvarenden.nationaal-archief. $\mathrm{nl} />$.

Orphan Chamber, 1809. Inventories of the Orphan Chamber. Cape Town Archives Repository, Cape Town: National Archives of South Africa, nr MOOC8/58.17b

Pama, C. 1983. Die groot Afrikaanse familienaamboek. Kaapstad: Human \& Rousseau.

Penn, N. 2005. The Forgotten Frontier: Colonist and Khoisan on the Cape's Northern Frontier in the 18th Century. Athens: Ohio University Press.

Philip, P. 1979. “Discharged Soldiers and Sailors Who Were Granted Permission to Remain at the Cape: 1815 -1824." Supplementa ad Familia I, 16 (3).

“Polish settlers in South Africa (1652-1910)." Geni.com. 18 Mar. 2015. <www.geni.com/ projects/Polish-settlers-in-South-Africa-1652-1910/15941>.

Preez, M. du. 2008. Of Tricksters, Tyrants and Turncoats: More Unusual Stories from South Africa's Past. Cape Town: Zebra Press.

Rensburg, A.M. van. 1999. “Jan Latsky a Centurion.” Familia: Quarterly Journal of the Genealogical Society of South Africa 36(4): 149

"Retired Soldiers who settled at the Cape 1818-1826, WO, 23/147." National Archives. Kew, UK transcribed by Charles Fison. 18 Apr. 2014. <www.geni.com/projects/Retired-Soldiers-who-settled-at-the-Cape-1818-1826/14029>.

Robertson, D. The First Fifty Years Project. 18 Apr. 2014. <http://www.e-family.co.za/ ffy $/>$.

Schmidt, W. 1955. Deutsche Wanderung nach Südafrika im 19. Jahrhundert. Berlin: D. Reimer.

Shell, R.C.H. 2005. “The Forgotten Factor in Cape Colonial Frontier Expansion: 1658-1817." Safundi: The Journal of South African and American Comparative Studies 6(2): 1-38.

“Sowietsky, Johan Michael." Profile on Geni.com. 18 Apr. 2014. <www.geni.com/people/ Johan-SOWIETSKY/6000000001524363653>.

Teenstra, M.D. 1943. De vruchten mijner werkzaamheden, gedurende mijne reize, over de Kaap de Goede Hoop, naar Java, en terug. Kaapstad: Die Van Riebeeck-Vereniging.

Villiers, S.A de. 1971. Robben Island: Out of Reach, Out of Mind: A History of Robben Island. Cape Town: C. Struik.

Villiers, C.C. de, and Pama, C. 1966. Geslagsregisters van die ou Kaapse families. Kaapstad: Balkema.

VOC. 1727. Resolutions of the Council of Policy of Cape of Good Hope. Cape Town Archives Repository, South Africa, C. 76: 124-127.

VOC. 1729. Resolutions of the Council of Policy of Cape of Good Hope. Cape Town Archives Repository, South Africa, C. 83: 59-68.

VOC. 1735. Resolutions of the Council of Policy of Cape of Good Hope. Cape Town Archives Repository, South Africa, C. 98: 9-12

“White Pages." 2015. Trudon. 18 Mar. 2015. <http://www.whitepages.co.za>.

Zöllner, L. 1991. Die nasate van die Rynse sendelinge in Suid-Afrika. Pretoria: Human Sciences Research Council.

Żukowski, A. 1994. W kraju złota i diamentów: Polacy w Potudniowej Afryce XVI-XX w. Warszawa: Wydawnictwo Naukowe PWN. 
. 2001. “Udział Polaków w formacjach wojskowych i porządkowych w Afryce Południowej na przestrzeni wieków." Polacy i osoby polskiego pochodzenia w siłach zbrojnych i policji państw obcych: Historia i wspótczesność. Materiaty VI Międzynarodowego Sympozjum Biografistyki Polonijnej. Eds A. Judycka, and Z. Judycki. Torun: Instytut Badań Biograficznych. 584-593.

. 2005. "Servicemen from the Kingdom of Poland in the Dutch East India Company and Their South African Connections." Slavic Almanach: The South African Journal for Slavic, Central and Eastern European Studies 11(1): 96-106. 